\title{
EFEKTIVITAS PELAYANAN PUBLIK DALAM MENINGKATKAN INDEKS KEPUASAN MASYARAKAT DI KECAMATAN JATINANGOR KABUPATEN SUMEDANG PROVINSI JAWA BARAT
}

\author{
Oleh \\ Raden Wijaya ${ }^{1}$, Rezky Aprilia ${ }^{2}$ \\ ${ }^{1,2}$ Institut Pemerintahan Dalam Negeri \\ radenwijaya3006@gmail.com
}

\begin{abstract}
$T$ he level of community satisfaction is one of the benchmarks, whether the services provided are acceptable or not. This study aims to determine and examine the implementation of Public Services carried out by Jatinangor District in increasing the community satisfaction index and to understand what factors increase the community satisfaction index in improving Public Services in Jatinangor District.

The method used in this research is inductive method. The Scope of this Research The independent variable used is the Community Satisfaction Index with the approval of the Minister of Administrative Reform Number 25 of 2004 concerning Guidelines for Preparation of Government Institution Service IKM Units. Data collection techniques using observation, interviews, documentation and questionnaires. Data obtained using interviews and questionnaires will then be analyzed using the score and percentage techniques.

From the results of the research to date, it is related to the government in the district, the timeliness and cost of getting services, as well as getting convenience, as well as comfort and security in getting services. In Jatinangor Regency, what is meant is productivity, quality, efficiency, efficiency, satisfaction and satisfaction.
\end{abstract}

Keywords: effectiveness, public services, community satisfaction index

\section{ABstrak}

$\mathrm{T}$ ngkat kepuasan masyarakat menjadi salah satu tolok ukur, apakah pelayanan yang diberikan dapat dikatakan baik atau tidak. Penelitian ini bertujuan untuk mengetahui dan mengkaji efektivitas pelaksanaan Pelayanan Publik yang dilaksanakan oleh Kecamatan Jatinangor dalam meningkatkan indeks kepuasan masyarakat serta untuk mengetahui faktor apa saja yang memengaruhi indeks kepuasan masyarakat dalam meningkatkan efektivitas Pelayanan Publik di Kecamatan Jatinangor.

Metode yang digunakan dalam penelitian adalah pendekatan induktif. Ruang Lingkup Penelitian ini variabel bebas yang digunakan adalah Indeks Kepuasan Masyarakat dengan mengacu pada Keputusan Menteri Pendayagunaan Aparatur Negara Nomor 25 Tahun 2004 tentang Pedoman Penyusunan IKM Unit Pelayanan Instansi Pemerintah. Teknik pengumpulan data menggunakan Observasi (Pengamatan), Wawancara, Dokumentasi dan Kuesioner. Data yang diperoleh dengan menggunakan wawancara dan kuesioner kemudian akan dianalisis menggunakan teknik skor dan persentase. 
Dari hasil penelitian menunjukkan bahwa masih dinilai kurang oleh masyarakat, yaitu penilaian terhadap kinerja aparat di kecamatan, ketepatan waktu juga biaya dalam mendapatkan pelayanan, keadilan mendapatkan pelayanan, serta kenyamanan dan keamanan dalam mendapatkan pelayanan. Hal ini diketahui berdasarkan beberapa indikator efektivitas yang digunakan untuk mengukur apakah sudah efektif pelaksanaan Pelayanan Publik di Kecamatan Jatinangor di antaranya, yaitu produktivitas, mutu atau kualitas, efisiensi, fleksibilitas dan kepuasan.

Kata kunci: efektivitas, pelayanan publik, indeks kepuasan masyarakat

\section{PENDAHULUAN}

$\mathrm{M}$ enurut Undang-Undang Nomor 25 Tahun 2009 tentang Pelayanan Publik sebagai upaya peningkatan kualitas dan menjamin penyediaan Pelayanan Publik sesuai dengan asas-asas umum pemerintahan yang baik, serta untuk memberi perlindungan bagi setiap warga negara dari penyalahgunaan wewenang. Sesuai dengan fungsi utama pemerintah daerah menurut Undang-Undang Nomor 22 Tahun 1999 yang diamendemen menjadi Undang-Undang Nomor 32 Tahun 2004 bahwa pemerintah merupakan sebagai fungsi pelayanan bagi masyarakat. Berdasarkan dari paradigma tersebut aparat pemerintah daerah khususnya kecamatan dituntut untuk mendapatkan pelayanan optimal kepada masyarakat.

Kecamatan merupakan salah satu lembaga pemerintahan yang memberikan pelayanan secara langsung kepada masyarakat. Kecamatan diperlukan untuk memberikan pelayanan kepada masyarakat berkaitan dengan hak sebagian warga negara, fungsi perizinan terbatas, dan administrasi kependudukan. Kecamatan Jatinangor yang letaknya sangat strategis dan memiliki masyarakat yang sangat beragam dan kompleks sehingga Kecamatan Jatinangor menjadi pusat pelayanan. Kecamatan Jatinangor sudah seharusnya memberikan pelayanan yang maksimal kepada masyarakat. Selain melayani berbagai urusan pelayanan administratif kependudukan dan perizinan, pemerintah kecamatan juga mengemban tugas melaksanakan pelayanan dasar sektoral, mulai dari urusan ketertiban dan keamanan, pendidikan, kesehatan, pengentasan kemiskinan, pemberdayaan masyarakat dan upaya-upaya konkret menyejahterakan masyarakat.

Berbagai upaya yang telah dilakukan Pemerintah Kecamatan Jatinangor untuk menghasilkan pelayanan yang lebih cepat, tepat, efisien dan dapat memenuhi kebutuhan masyarakat itu sendiri. Namun upaya-upaya yang dilakukan oleh Pemerintah Kecamatan Jatinangor dirasa belum optimal. Salah satu indikator yang dapat dilihat adalah masih banyaknya masyarakat yang mengeluh dengan pelayanan yang diberikan aparatur kecamatan. Pelayanan Publik yang seharusnya memudahkan masyarakat dalam menerima pelayanan, masih dirasakan belum optimal. Prosedur yang berbelit-belit, Standar Operasional Prosedur yang kurang jelas, lambannya pelayanan yang diberikan oleh aparat kecamatan karena kurangnya disiplin pegawai terhadap jam kerja, adanya kecenderungan perbedaan perlakuan dari aparat pemerintah dalam proses pelayanan serta masih adanya pungutan di luar biaya resmi untuk memperlancar pemberian pelayanan, menjadi masalah bagi masyarakat untuk menerima pelayanan yang ada di Kecamatan Jatinangor. Kurangnya sarana dan prasarana yang ada di Kecamatan Jatinangor, serta kepastian waktu yang tidak jelas, mengakibatkan pemberian layanan oleh aparat kecamatan terhadap masyarakat menjadi belum optimal. Masyarakat pun mengasumsikan bahwa pelayanan yang dilaksanakan oleh aparatur kecamatan ini cenderung menjadi kurang memuaskan. 
Ukuran keberhasilan penyelenggaraan pelayanan, ditentukan dengan tingkat kepuasan penerima pelayanan. Kepuasan penerima pelayanan dicapai apabila penerima pelayanan memperoleh pelayanan sesuai dengan yang dibutuhkan dan diharapkan. Tingkat kepuasan masyarakat menjadi salah satu tolok ukur, apakah pelayanan yang diberikan dapat dikatakan baik atau tidak. Tingkat kepuasan pelanggan terhadap pelayanan yang diberikan dapat dilihat dari penggunaan teknologi yang canggih, waktu pelayanan yang efektif dan efisien, dan sarana prasarana yang memadai sehingga pelayanan dapat dilakukan secara maksimal. Oleh karena itu dalam kaitan dengan tingkat kepuasan masyarakat, Menteri Pendayagunaan Aparatur Negara mengamanatkan agar setiap penyelenggaraan pelayanan secara berkala melakukan survei indeks kepuasan masyarakat. Indeks kepuasan Masyarakat adalah data dan informasi tentang tingkat kepuasan masyarakat yang diperoleh dari hasil pengukuran secara kuantitatif (teknik penghitungan IKM) atas pendapat masyarakat dalam memperoleh pelayanan dari aparatur penyelenggara Pelayanan Publik dengan membandingkan antara harapan dan kebutuhannya.

\section{KAJIAN TEORETIS}

Kriteria efektivitas dengan menggunakan teori dari Gibson dan Steers. Menurut Gibson dan Steers (1997:28) dalam Sumaryadi (2005:107-108) menjelaskan:

1. Produksi atau produktivitas, mencerminkan kemampuan organisasi dalam menghasilkan sejumlah barang dan jasa seperti yang dituntut lingkungan;

2. Mutu atau kualitas, produk yang memenuhi harapan pelanggan dan klien untuk kinerja produk dan jasa, dengan ukuran dan penilaian mutu berasal dari pelanggan dan masyarakat;
3. Efisiensi diartikan sebagai rasio keluaran dibanding masukan, memfokuskan pada siklus, masukan-proses-keluaran dan bahkan menekankan pada elemen masukan dan proses;

4. Fleksibilitas menyangkut kemampuan organisasi untuk mengalihkan sumber daya dari aktivitas yang lain guna menghasilkan produk dan pelayanan yang baru dan berbeda, menanggapi permintaan masyarakat;

5. Kepuasan ditujukan pada perasaan masyarakat terhadap pekerjaan mereka dan peran di organisasi serta pertimbangan manfaat yang diterima partisipan, demikian oleh pelanggan dan masyarakat.

Penggunaan teori efektivitas untuk menganalisis apakah variabel yang diteliti telah berjalan efektif atau sebaliknya. Konsep efektivitas yang dimaksud adalah efektivitas Pelayanan Publik dalam meningkatkan indeks kepuasan masyarakat, sehingga dapat menggambarkan bagaimana tingkat kepuasan masyarakat dalam menerima Pelayanan Publik sudah efektif khususnya di Kecamatan Jatinangor, maka dalam penelitian ini mengacu pada pendekatan proses, karena penelitian ini bertujuan untuk mengetahui efektivitas pelayanan pemerintah di Kantor Kecamatan.

Berdasarkan Undang-Undang tentang Pelayanan Publik, yaitu Undang-Undang Nomor 25 Tahun 2009 Bab I Pasal 1 ayat 1, Pelayanan Publik adalah kegiatan atau rangkaian kegiatan dalam rangka pemenuhan kebutuhan pelayanan sesuai dengan peraturan perundang-undangan bagi setiap warga Negara dan penduduk atas barang, jasa dan/atau pelayanan administratif yang disediakan oleh penyelenggara Pelayanan Publik.Sedangkan pengertian Pelayanan Publik berdasarkan Kep MenPAN Nomor: KEP/25/M. PAN/2/2004, "Pelayanan Publik adalah segala kegiatan pelayanan yang dilaksanakan oleh penyelenggara Pelayanan 
Publik sebagai upaya pemenuhan kebutuhan penerima pelayanan, maupun dalam rangka pelaksanaan ketentuan peraturan perundang-undangan." Berdasarkan Keputusan Menteri Pendayagunaan Aparatur Negara Nomor 25 Tahun 2004 Indeks Kepuasan Masyarakat adalah data dan informasi tentang kepuasan masyarakat yang diperoleh dari hasil pengukuran secara kuantitatif dan kualitatif atas pendapat masyarakat dalam memperoleh pelayanan dari aparatur penyelenggara Pelayanan Publik dengan membandingkan antara harapan dan kebutuhannya. Surat Keputusan Menteri Pendayagunaan Aparatur Negara Nomor 26 Tahun 2004 tentang Petunjuk Teknis Transparansi dan Akuntabilitas dalam Penyelenggaraan Pelayanan Publik, yang dimaksud dan tujuan dari Indeks Kepuasan Masyarakat (IKM) adalah sebagai acuan bagi seluruh penyelenggara Pelayanan Publik untuk meningkatkan kualitas transparansi dan akuntabilitas pelayanan serta memberi kejelasan bagi seluruh penyelenggara Pelayanan Publik dalam melaksanakan Pelayanan Publik.

Adapun manfaat penyusunan indeks kepuasan masyarakat dalam Keputusan Menteri Pendayagunaan Aparatur Negara Nomor 25 Tahun 2004, yaitu: (1) Diketahui kelemahan atau kekurangan dari masingmasing unsur dalam penyelenggaraan Pelayanan Publik, (2) Diketahui kinerja penyelenggaraan pelayanan yang telah dilaksanakan oleh unit Pelayanan Publik secara periodik. (3) sebagai bahan penetapan kebijakan yang perlu diambil dan upaya yang perlu dilakukan. (4) Diketahui indeks kepuasan masyarakat secara menyeluruh terhadap hasil pelaksanaan Pelayanan Publik pada lingkup Pemerintah Pusat dan Daerah, dan (5) Bagi masyarakat dapat diketahui gambaran tentang kinerja unit pelayanan.

Dalam Pedoman Umum Penyusunan Indeks Kepuasan Masyarakat Unit Pelayanan Pemerintah terdapat 14 unsur indeks kepuasanmasyarakat,yaitusebagaiberikut.
1. Prosedur pelayanan, yaitu kemudahan tahapan pelayanan yang diberikan kepada masyarakat dilihat dari sisi kesederhanaan alur pelayanan;

2. Persyaratan pelayanan, yaitu persyaratan teknis dan administratif yang diperlukan untuk mendapatkan pelayanan sesuai dengan jenis pelayanannya;

3. Kejelasan petugas pelayanan, yaitu keberadaan dan kepastian petugas yang memberikan pelayanan (nama, jabatan serta kewenangan dan tanggung jawabnya);

4. Kedisiplinan petugas pelayanan, yaitu kesungguhan petugas dalam memberikan pelayanan terutama terhadap konsistensi waktu kerja sesuai ketentuan yang berlaku;

5. Tanggung jawab petugas pelayanan, yaitu kejelasan wewenang dan tanggung jawab petugas dalam penyelenggaraan dan penyelesaian pelayanan;

6. Kemampuan petugas pelayanan, yaitu tingkat keahlian dan keterampilan yang dimiliki petugas dalam memberikan/ menyelesaikan pelayanan kepada masyarakat;

7. Kecepatan pelayanan, yaitu target waktu pelayanan dapat diselesaikan dalam waktu yang telah ditentukan oleh unit penyelenggara pelayanan;

8. Keadilan mendapatkan pelayanan, yaitu pelaksanaan pelayanan dengan tidak membedakan golongan/status masyarakat yang dilayani;

9. Kesopanan dan keramahan petugas, yaitu sikap dan perilaku petugas dalam memberikan pelayanan kepada masyarakat secara sopan dan ramah serta saling menghargai dan menghormati;

10. Kewajaran biaya pelayanan, yaitu keterjangkauan masyarakat terhadap besarnya biaya yang ditetapkan oleh unit pelayanan; 
11. Kepastian biaya pelayanan, yaitu kesesuaian antara biaya yang dibayarkan dengan biaya yang telah ditetapkan;

12. Kepastian jadwal pelayanan, yaitu pelaksanaan waktu pelayanan, sesuai dengan ketentuan yang telah ditetapkan;

13. Kenyamanan lingkungan, yaitu kondisi sarana dan prasarana pelayanan yang bersih, rapi, dan teratur sehingga dapat memberikan rasa nyaman kepada penerima pelayanan;

14. Keamanan Pelayanan, yaitu terjaminnya tingkat keamanan lingkungan unit penyelenggara pelayanan ataupun sarana yang digunakan, sehingga masyarakat merasa tenang untuk mendapatkan pelayanan terhadap risiko-risiko yang diakibatkan dari pelaksanaan pelayanan.

Tabel 1 Variabel, Sub Variabel dan Indikator

\section{METODE PENELITIAN}

Adapun pendekatan penelitian yang digunakan dalam penelitian ini adalah pendekatan induktif, yaitu suatu pendekatan dengan mengambil simpulan secara umum dari fakta-fakta nyata yang ada di lapangan. Induktif merupakan cara berpikir, di mana ditarik simpulan yang bersifat umum dari berbagai kasus yang bersifat individual. Ruang Lingkup Penelitian ini variabel bebas yang digunakan adalah Indeks Kepuasan Masyarakat, di mana Indeks Kepuasan Masyarakat digunakan untuk mengukur kepuasan Masyarakat guna meningkatkan kualitas pelayanan Pelayanan Publik di Kecamatan Jatinangor dengan mengacu pada Keputusan Menteri Pendayagunaan Aparatur Negara Nomor 25 Tahun 2004 tentang Pedoman Penyusunan IKM Unit Pelayanan Instansi Pemerintah. Untuk lebih jelasnya, dapat dilihat dalam tabel 1.

\begin{tabular}{|l|l|l|}
\hline VARIABEL & \multicolumn{1}{|c|}{ SUB VARIABEL } & \multicolumn{1}{|c|}{ INDIKATOR } \\
\hline \multirow{4}{*}{$\begin{array}{l}\text { Efektivitas } \\
\text { Pelayanan }\end{array}$} & 1. Produksi atau produktivitas & $\begin{array}{l}\text { 1. Pelaksanaan Pelayanan Publik guna } \\
\text { memenuhi kebutuhan masyarakat akan } \\
\text { pelayanan }\end{array}$ \\
\cline { 2 - 4 } & 2. Mutu dan Kualitas & $\begin{array}{l}\text { 2. Produk Pelayanan Pelayanan Publik di } \\
\text { Kecamatan Jatinangor }\end{array}$ \\
\cline { 2 - 4 } & 3. Efisiensi & $\begin{array}{l}\text { Kesesuaian kinerja aparat kecamatan } \\
\text { dalam Pelayanan Publik }\end{array}$ \\
\cline { 2 - 4 } & 4. Fleksibilitas & $\begin{array}{l}\text { 1. Perbandingan antara input dan output } \\
\text { dalam pelaksanaan Pelayanan Publik } \\
\text { Peningkatan sarana dan prasarana } \\
\text { pelayanan }\end{array}$ \\
\hline $\begin{array}{l}\text { V a r i a b e l } \\
\text { I n d e k s } \\
\text { Ke pua s a n } \\
\text { Masyarakat }\end{array}$ & 1. Prosedur Pelayanan & $\begin{array}{l}\text { Kemampuan aparat dalam memberikan } \\
\text { Pelayanan Publik Pembaharuan atau } \\
\text { inovasi dalam peningkatan Pelayanan } \\
\text { Publik }\end{array}$ \\
\cline { 2 - 4 } & 5. Kepuasan & $\begin{array}{l}\text { Sikap yang diterima masyarakat dari hasil } \\
\text { program Pelayanan Publik }\end{array}$ \\
\hline
\end{tabular}




\begin{tabular}{|l|l|l|}
\hline & 2. Persyaratan Pelayanan & Persyaratan teknis \\
\hline & 3. Kejelasan Petugas Pelayanan & Kepastian aparat \\
\hline & $\begin{array}{l}\text { 4. Kedisiplinan Petugas } \\
\text { Pelayanan }\end{array}$ & Kesungguhan aparat \\
\hline & $\begin{array}{l}\text { 5. Tanggung Jawab Petugas } \\
\text { Pelayanan }\end{array}$ & Kejelasan tanggung jawab \\
\hline & $\begin{array}{l}\text { Celayanan } \\
\text { 7. Kecepatan Pelayanan }\end{array}$ & Tingkat keahlian aparat \\
\hline & $\begin{array}{l}\text { 8. Keadilan mendapatkan } \\
\text { Pelayanan }\end{array}$ & Keadilan pelayanan \\
\hline & $\begin{array}{l}\text { 9. Kesopanan dan Keramahan } \\
\text { Petugas }\end{array}$ & Sikap aparat \\
\hline & 10. Kewajaran Biaya Pelayanan & Keterjangkauan biaya \\
\hline & 11. Kepastian Biaya Pelayanan & Kesesuaian biaya \\
\hline & 12. Kepastian Jadwal Pelayanan & Kesesuaian waktu pelayanan \\
\hline & 14. Kenyamanan Lingkungan & Kondisi sarana dan prasarana \\
\hline
\end{tabular}

Sumber : Diolah Peneliti Mengacu pada

Dalam penelitian ini, informan yang ditentukan oleh peneliti Camat, Sekretaris Camat, Kasi Pelayanan Umum dan Masyarakat. Teknik pengumpulan data menggunakan Observasi (Pengamatan), Wawancara, Dokumentasi dan Kuesioner. Data yang diperoleh dengan menggunakan wawancara dan kuesioner kemudian akan dianalisis menggunakan teknik skor dan persentase. Dari total skor yang dan persentase yang didapat, kemudian menarik interprestasi dari angka yang diperoleh sehingga data-data yang berupa skor tersebut dapat dipahami dan menjadi simpulan.

Untuk menghitung IKM, yaitu dengan menghitung nilai rata-rata tertimbang pada masing-masing unsur pertanyaan dengan jenis data berupa data ordinal. Metode perhitungan angka indeks digunakan nilai rata-rata tertimbang dari masing-masing unsur pertanyaan dengan perhitungan ratarata tertimbang sebagai berikut.

\section{Penentuan Skor Jawaban}

Untuk menentukan penilaian terhadap jawaban yangtelah diberikan oleh responden, maka penulis merujuk pada Pedoman Umum Penyusunan Indeks Kepuasan Masyarakat (IKM). (Kep MenPAN No. 25 Tahun 2004). Dengan pedoman tersebut, penulis menggunakan standar nilai, yaitu:

- Untuk jawaban huruf a dengan bobot nilai 1;

- Untuk jawaban huruf b dengan bobot nilai 2;

- Untuk jawaban huruf c dengan bobot nilai 3;

- Untuk jawaban huruf d dengan bobot nilai 4.

\section{Penentuan Prestasi}

Penulis menentukan prestasi jawaban dengan merujuk pada Kep Men PAN No. 25 Tahun 2004. Nilai IKM dihitung dengan menggunakan "nilai rata-rata tertimbang" 
masing-masing unsur pelayanan. Dalam penghitungan Indeks Kepuasan Masyarakat terhadap empat belas unsur pelayanan memiliki penimbang yang sama dengan rumus sebagai berikut.

Untuk memperoleh nilai IKM unit pelayanan digunakan pendekatan nilai rata-rata tertimbang dengan rumus sebagai berikut.

\section{IKM = Total dari Nilai Prestasi Per Unsur X Nilai Penimbang \\ Total unsur yang terisi}

Untuk memudahkan interprestasi terhadap penilaian IKM, yaitu antara 25 -100 maka hasil penelitian di atas dikonversikan dengan nilai dasar 25 , dengan rumus sebagai berikut:

\section{IKM Unit Pelayanan x 25}

\section{Penentuan Kriteria Hasil Skor}

Untuk mengetahui atau menentukan kriteria jawaban dari responden maka penulis merujuk pada Pedoman Umum Penyusunan Indeks Kepuasan Masyarakat (IKM). Dengan menggunakan tabel:

Tabel 2 Nilai Persepsi, Interval IKM, Interval Konversi IKM, Mutu Pelayanan Dan Kinerja Unit Pelayanan

\begin{tabular}{|c|c|c|c|l|}
\hline $\begin{array}{c}\text { Nilai } \\
\text { Persepsi }\end{array}$ & $\begin{array}{c}\text { Nilai Interval } \\
\text { IKM }\end{array}$ & $\begin{array}{c}\text { Nilai Interval } \\
\text { Konversi IKM }\end{array}$ & $\begin{array}{c}\text { Mutu } \\
\text { Pelayanan }\end{array}$ & $\begin{array}{c}\text { Kinerja Unit } \\
\text { Pelayanan }\end{array}$ \\
\hline 1 & $1.00-1,75$ & $25,00-43,75$ & A & Tidak Baik \\
\hline 2 & $1,76-2,50$ & $43,76-62,50$ & B & Kurang Baik \\
\hline 3 & $2,52-3,25$ & $62,51-81,25$ & C & Baik \\
\hline 4 & $3,25-4,00$ & $81,26-100,00$ & D & Sangat Baik \\
\hline
\end{tabular}

Sumber : Kep. MenPAN No. 25 Tahun 2004

\section{HASIL DAN PEMBAHASAN}

Rekapitulasi Hasil Penilaian Kualitas Pelayanan Ditinjau dari Indeks Kepuasan Masyarakat dalam Pelayanan Publik

Tabel 3 Penilaian Masyarakat Berdasarkan Indeks Kepuasan Masyarakat (IKM)

\begin{tabular}{|c|l|c|c|}
\hline No. & Unsur Pelayanan & Nilai Unsur Pelayanan & Nilai Indeks \\
\hline 1 & Prosedur pelayanan & 2,58 & 0,18 \\
\hline 2 & Persyaratan pelayanan & 2,86 & 0,20 \\
\hline 3 & Kejelasan petugas pelayanan & 2,86 & 0,20 \\
\hline 4 & Kedisiplinan petugas pelayanan & 2,84 & 0,20 \\
\hline 5 & Tanggung jawab petugas pelayanan & 2,94 & 0,21 \\
\hline 6 & Kemampuan petugas pelayanan & 2,96 & 0,21 \\
\hline 7 & Kecepatan pelayanan & 2,57 & 0,18 \\
\hline 8 & Keadilan mendapatkan pelayanan & 2,88 & 0,20 \\
\hline 9 & Kesopanan dan keramahan petugas & 3,01 & 0,21 \\
\hline 10 & Kewajaran biaya pelayanan & 2,92 & 0,21 \\
\hline
\end{tabular}




\begin{tabular}{|c|l|c|c|}
\hline 11 & Kepastian biaya pelayanan & 2,61 & 0,18 \\
\hline 12 & Kepastian jadwal pelayanan & 2,55 & 0,18 \\
\hline 13 & Kenyamanan lingkungan & 2,65 & 0,18 \\
\hline 14 & Keamanan pelayanan & 2,94 & 0,21 \\
\hline & Jumlah Nilai Indeks & \multicolumn{2}{|c|}{ B } \\
\hline & IKM Unit Pelayanan & \multicolumn{2}{|c|}{ Baik } \\
\hline & Mutu Pelayanan & \multicolumn{2}{|c|}{} \\
\hline & Kinerja Unit Pelayanan & \multicolumn{2}{|c|}{} \\
\hline
\end{tabular}

Sumber: Modifikasi Penulis Mengacu pada Kep MenPan Nomor 25 Tahun 2004

Hasil penilaian 150 orang responden terhadap 14 unsur Indeks Kepuasan Masyarakat bahwa kualitas pelayanan Pelayanan Publik di Kantor Kecamatan Jatinangor termasuk ke dalam kategori B dengan nilai Indeks 70,75 yang berarti kinerja di unit pelayanan yang diberikan termasuk baik.

\section{HASIL DAN PEMBAHASAN}

Dalam memberikan Pelayanan Publik di Kantor Kecamatan Jatinangor ini sudah cukup baik, hal ini dapat dilihat tabel berikut ini:

Tabel 4 Produktivitas Jumlah Warga yang Terlayani Oleh Aparat Kecamatan Jatinangor Dalam Paten Bulan Januari-Februari 2020

\begin{tabular}{|c|c|c|c|c|c|}
\hline \multirow{3}{*}{ No } & \multirow{3}{*}{ JENIS PELAYANAN } & \multicolumn{4}{|c|}{ JUMLAH PERMINTAAN LAYANAN } \\
\hline & & \multicolumn{2}{|c|}{ JANUARI } & \multicolumn{2}{|c|}{ FEBRUARI } \\
\hline & & * & $* *$ & * & ** \\
\hline 1. & Surat Izin Mendirikan Bangunan (IMB) & 60 & 54 & 65 & 51 \\
\hline 2. & Izin Undang-undang Gangguan (HO) & 42 & 37 & 28 & 24 \\
\hline 3. & Izin Peruntukan Penggunaan Tanah (IPPT) & 32 & 32 & 26 & 23 \\
\hline 4. & Pembuatan Kartu Keluarga & 98 & 89 & 107 & 101 \\
\hline 5. & Pembuatan KTP & 143 & 137 & 165 & 149 \\
\hline 6. & Surat Keterangan Pendaftaran Penduduk Tetap & 87 & 76 & 91 & 80 \\
\hline 7. & Surat Keterangan Penduduk Sementara & 162 & 156 & 172 & 169 \\
\hline 8. & Surat Keterangan Pindah Antarkecamatan & 42 & 36 & 38 & 36 \\
\hline 9. & Surat Keterangan Kelakuan Baik & 149 & 135 & 143 & 102 \\
\hline 10. & Surat Ahli Waris & 12 & 12 & 9 & 8 \\
\hline 11. & Surat Permohonan Kredit Perbankan & 201 & 189 & 107 & 102 \\
\hline 12. & Akta Jual Beli & 76 & 75 & 45 & 45 \\
\hline 13. & Akta Waris & 12 & 12 & 9 & 8 \\
\hline 14. & Akta Hibah & 8 & 8 & 7 & 5 \\
\hline 15. & Dokumen Lain-lain & 1341 & 1246 & 1150 & 1026 \\
\hline
\end{tabular}

Sumber: Buku Pelayanan Kecamatan Jatinangor, 2020

Keterangan :

* Jumlah permintaan Pelayanan

** Jumlah permintaan Pelayanan yang terlayani 
Berdasarkan tabel diatas dapat diketahui bahwa Pelayanan Publik telah berjalan cukup efektif. Hal ini terlihat dari jumlah produk layanan permintaan masyarakat akan Pelayanan Publik yang dapat dipenuhi ratarata sebesar $92 \%$ per bulan. Produktivitas ini jauh meningkat dibandingkan tahun 20182019 yang hanya mampu mencapai 86\% saja per bulan. Peningkatan produktivitas ini disebabkan karena adanya penambahan jumlah peralatan yang awalnya hanya sebanyak 3 unit komputer dan 2 printer ditambah menjadi 5 unit komputer dan 6 printer.

Pemberian produk Pelayanan Publik ini dirasa sudah baik. Hal ini di dapat terjadi karena didukung oleh kinerja aparatur Kecamatan Jatinangor yang semakin baik. Terutama dari petugas pemberi pelayanan yang berhadapan langsung dengan masyarakat yakni petugas pemberi pelayanan yang ada di loket depan. Petugas pemberi layanan yang semakin bekerja secara produktif. Karena pada dasarnya petugas pemberi pelayanan memberikan layanan sesuai alur yang ditentukan. Tetapi dilihat dari kenyataannya, petugas yang memberikan pelayanan masih dirasa kurang. Karena pada semestinya petugas pemberi pelayanan itu idealnya berjumlah 6 orang dengan mempunyai tupoksi nya masingmasing yang dalam hal ini dibutuhkan Petugas Informasi, Petugas Penerima Berkas, Petugas Pendaftaran, Petugas Pengagendaan, Petugas Pemprosesan Pelayanan dan Petugas Pengaduan. Tetapi dalam kenyataannya petugas pemberi layanan dari mulai informasi sampai pengaduan hanya berjumlah 3 orang saja. Tetapi dengan kekurangan petugas pemberi pelayanan itu tidak membuat dalam pemberian pelayanan kepada masyarakat menjadi terbengkalai. Walaupun petugas pemberi pelayanan yang hanya berjumlah tiga orang saja tetapi pemberian pelayanan tetap berjalan dengan baik dan produktif. Berdasarkan penelitian tingkat produktivitas Pelayanan Publik dinilai cukup baik, hal ini dapat dilihat dari jumlah produk pelayanan yang dihasilkan dalam sehari. Biasanya masyarakat yang meminta pelayanan dalam sehari bisa mencapai 70 sampai 80 produk layanan. Dan dalam hari itu produk pelayanan yang dihasilkan bisa mencapai 55 sampai 60 produk pelayanan. Kecamatan Jatinangor sudah berusaha melayani masyarakat secara baik, dengan waktu yang sesingkat mungkin dan tidak bertele-tele. Walaupun ada sebagian masyarakat yang masih kurang puas akan pelayanan yang diberikan oleh aparat kecamatan. Hal ini disebabkan salah satunya karena kurangnya SDM yang ada di kecamatan terutama petugas pengelola administrasi. Petugas pengelola administrasi yang bertugas di loket pelayanan haya berjumlah tiga orang saja. Idealnya petugas pengelola administrasi berjumlah enam orang yang masing-masing petugas itu melayani dari informasi, penerima berkas, pendaftaran, pengagendaan dan penerima pengaduan. Agar semakin baik dan semakin meningkatnya produktivitas upaya yang dilakukan, yaitu dengan menambah petugas pengelola administrasi yang seharusnya berjumlah enam orang agar masing-masing petugasitumelayani dari informasi, penerima berkas, pendaftaran, pengagendaan dan penerima pengaduan. Apabila keenam petugas itu sudah dipenuhi maka dalam memberikan pelayanan kepada masyarakat akan lebih cepat, mudah, dan tepat waktu sehingga produktivitas meningkat.

Penulis juga melakukan penelitian dengan pengumpulan data melalui kuesioner mengenai Indeks Kepuasan Masyarakat. Hasil penilaian responden yang melakukan Pelayanan Publik di Kantor Kecamatan Jatinangor terhadap 14 unsur Indeks Kepuasan Masyarakat menunjukkan jumlah Nilai Indeks adalah 2,83, Indeks Kepuasan Masyarakat Unit Pelayanan adalah 68,75 dengan kategori mutu "B", yang menunjukkan bahwa Kinerja Unit Pelayanan di Kantor Kecamatan 
Jatinangor adalah "baik". Berdasarkan data tersebut disimpulkan bahwa kualitas Pelayanan Publik yang diberikan oleh aparatur Kecamatan Jatinangor sudah termasuk cukup baik, walaupun masih terdapat beberapa kekurangan, di antaranya lamanya pemprosesan pembuatan dokumen pelayanan yang menyebabkan tidak adanya kepastian waktu penyelesaian Pelayanan. Selain itu masih dihasilkan masih dirasa kurang memuaskan masyarakat.

Faktor-Faktor yang Memengaruhi Efektivitas Pelayanan Publik dalam Meningkatkan Indeks Kepuasan Masyarakat

Menilai suatu kinerja pelayanan suatu organisasi pada dasarnya adalah melakukan identifikasi terhadap kesenjangan yang mungkin muncul antara harapan pelanggan sebagai penggunaan pelayanan dengan layanan yang mereka terima selama ini dari pemberi pelayanan dalam hal ini aparatur pemerintah. Berdasarkan hasil penelitian dan studi kepustakaan yang dilakukan penulis, bahwa terdapat hambatanhambatan dalam Pelayanan Publik, yakni (1) Hambatan Internal, dapat berupa keterbatasan dana, keterbatasan peralatan dan teknologi, kurang efektifnya manajemen dan kepemimpinan, masalah manajemen dan kepemimpinan dapat menyangkut kelemahan dalam suatu perencanaan, pengorganisasian, pengelolaan logistik dan mempersiapkan sumber daya manusia yang berkualitas; (2) Hambatan eksternal, Hambatan ini dapat muncul dari lingkungan kerja yang termasuk masyarakat sekitar, para pesaing yang secara sengaja membuat gangguan, para pemasok yang terlambat melakukan pengiriman dan kebijakan pemerintah yang tidak konsisten.

Beberapa faktor yang dapat menghambat efektivitas pelayanan publik dalam meningkatkan kepuasan masyarakat. Faktor-faktor tersebut, yaitu sebagai berikut. a. Kurangnya keterampilan dan kemampuan aparatur Kecamatan Jatinangor dalam memberikan Pelayanan Publik. Kendala bagi pemerintah Kecamatan Jatinangor dalam memberikan Pelayanan Publik kepada masyarakat yakni masyarakat masih kurang juga pelayanan di tingkat desa. Pelayanan oleh aparat desa masih dirasa kurang terutama dalam administrasi kependudukan. Aparat desa masih kurang mampu untuk mengaplikasikan data-data permohonan dari masyarakat untuk memvalidasi data sehingga nantinya akan di print out kemudian di lampirkan ke Kecamatan. Hal ini membuat terhambatnya kinerja di aparat kecamatan untuk melakukan pemprosesan data dari desa. Hal ini terjadi karena tidak semua desa dapat mengaplikasikan proses data yang selanjutnya di serahkan kepada kecamatan karena kurangnya Sumber Daya Manusia. Selain itu keterampilan dan kemampuan dari aparatur kecamatan juga yang tidak semua dapat mengoperasikan komputer. Dan tingkat kecepatan pegawai dalam melayani permintaan pelayanan masyarakat masih tergolong rendah, hal ini dapat dilihat dari jumlah produk pelayanan yang dihasilkan masih belum memenuhi permintaan pelayanan masyarakat.

b. Terbatasnya sarana dan prasarana yang menunjang pemberian Pelayanan Publik kepada masyarakat. Adanya keterbatasan sarana dan prasarana yang menunjang pemberian Pelayanan Publik kepada masyarakat sengat memengaruhi proses pemberian Pelayanan Publik, seperti kecepatan pelayanan yang terhambat, jumlah produk pelayanan yang tidak memenuhi permintaan pelayanan. Penunjang pelaksanaan Pelayanan Publik juga yang perlu diganti karena usia pemakaiannya yang sudah terlalu lama tetapi masih 
dibutuhkan sehingga memerlukan pemeliharaan yang rajin dan teliti. Jumlah perangkat komputer dan printer di kantor Kecamatan Jatinangor yang masih kurang mencukupi bila dibandingkan dengan jumlah permintaan pelayanan masyarakat yang semakin meningkat. Selain itu kondisi ruang pelayanan juga masih terbatas, ruang-ruang pemprosesan pelayanan karena ketidaknyamanan. Permintaan Pelayanan Publik dari masyarakat terus meningkat sedangkan alat yang digunakan tidak diganti atau ditambah sehingga semakin lama alat tersebut akan rusak.

c. Terbatasnya jumlah aparatur kecamatan yang bertugas memberikan pelayanan kepada masyarakat. Terbatasnya jumlah aparatur kecamatan yang bertugas memberikan pelayanan kepada masyarakat, khususnya bagian operasional da teknis yang bertugas khusus memproses dan menerbitkan dokumen pelayanan. Kurangnya tenaga operasional dan teknis ini menyebabkan sering terjadi keterlambatan dalam pemberian Pelayanan Publik kepada masyarakat dan jumlah produk pelayanan yang diminta tidak terpenuhi.

d. Kurangnya pemahaman masyarakat akan Pelayanan apa saja yang ada di Kecamatan. Masih banyak masyarakat yang tidak mengetahui pelayanan apa saja yang ada di kecamatan serta persyaratan apa saja yang harus dipenuhi. Hal ini disebabkan juga karena kurang meratanya sosialisasi yang dilakukan aparat kecamatan kepada masyarakat mengingat lokasi wilayah dari masyarakat yang berbeda-beda. Ada yang tinggal dekat dengan kecamatan ada yang tinggal jauh dari kecamatan.

e. Urusan administrasi perizinan, masih adanya keterkaitan dengan pihak lain. Proses perizinan Jatinangor sangat banyak melibatkan komponen masyarakat di dalamnya. Baik dari Paguyuban Pasundan, LSM, karang taruna, LPM ataupun tokoh-tokoh masyarakat lainnya. Contohnya dalam pembuatan apartemen dan tower semua elemen dan tokoh masyarakat di atas harus terlihat. Jadi dalam hal ini harus dilakukan beberapa kali pertemuan. Sehingga proses perizinan terkesan menjadi panjang, berbelitbelit, dan harus ada kompensasi yang diberikan kepada masyarakat untuk sewaktu-waktu apabila terjadi musibah masyarakat yang tinggal di sekitar mendapat ganti rugi. Untuk itu untuk pembuatan perizinan Ho memerlukan waktu da proses yang lama serta keterkaitan dengan pihak lain.

\section{Upaya yang di tempuh Pemerintah Kecamatan Jatinangor dalam mengefektifkan Pelayanan Publik dalam meningkatkan kepuasan kepada masyarakat}

Berikut beberapa upaya yang dilakukan oleh dalam mengefektifkan Pelayanan Publik dalam meningkatkan kepuasan kepada masyarakat:

1. Pengadaan diklat teknis dan manajerial dalam hal pelayanan bagi aparatur Kecamatan Jatinangor. Apabila keterampilan aparatur Kecamatan Jatinangor dapat meningkat, maka kualitas pelayanan pun akan meningkat;

2. Penganggaran untuk peningkatan sarana da prasarana pelayanan seperti penambahan komputer, printer dan perluasan pelayanan di kantor Kecamatan Jatinangor;

3. Untuk mengoptimalisasikan kinerja aparatur kecamatan dari segiterbatasnya jumlah aparatur kecamatan di bidang operasional dan teknis pelayanan, camat mengusulkan tambahan pegawai kepada BKD atau membuka lowongan tenaga 
sukarelawan yang ingin bekerja di Kantor Kecamatan Jatinangor. Pendekatan kepada tokoh masyarakat da adanya sosialisasi yang merata kepada seluruh masyarakat agar masyarakat paham dan mengetahui pelayanan yang ada di kecamatan. Apabila masyarakat sudah masyarakat sudah mengetahuinya, maka di harapkan masyarakat tidak bingung lagi dengan persyaratan yang harus di penuhi. Sehingga pelayanan yang dilakukan lebih cepat dan efisien.

\section{SIMPULAN}

Berdasarkan uraian di atas, maka dapat disimpulkan bahwa:

1. Secara umum Pelayanan Publik di Kecamatan Jatinangor Kabupaten Sumedang sudah berjalan secara efektif. Tetapi masih dinilai kurang oleh masyarakat, yaitu penilaian terhadap kinerja aparat di kecamatan, ketepatan waktu juga biaya dalam mendapatkan pelayanan, keadilan mendapatkan pelayanan, serta kenyamanan dan keamanan dalam mendapatkan pelayanan. Hal ini diketahui berdasarkan beberapa indikator efektivitas yang digunakan, yaitu produktivitas, mutu atau kualitas, efisiensi, fleksibilitas dan kepuasan. Selain itu untuk mengetahui bagaimana mengukur tingkat kepuasan masyarakat dalam menerima Pelayanan Publik di Kecamatan Jatinangor, yaitu dengan melakukan pengukuran Indeks Kepuasan Masyarakat (IKM). Di mana indikator IKM ini terdiri dari prosedur pelayanan, persyaratan pelayanan, kejelasan petugas pelayanan, kedisiplinan petugas, tanggung jawab petugas pelayanan, kemampuan petugas pelayanan, kecepatan pelayanan, keadilan mendapatkan pelayanan, kesopanan dan keramahan petugas, kewajaran biaya pelayanan, kepastian biaya pelayanan, kepastian jadwal pelayanan, kenyamanan lingkungan dan keamanan pelayanan

2. Faktor yang memengaruhi efektivitas Pelayanan Publik dalam meningkatkan indeks kepuasan masyarakat di Kecamatan Jatinangor, yaitu Berdasarkan dari konsep efektivitas bahwa untuk melihat sudah efektifnya Pelayanan Publik di Kecamatan Jatinangor dapat dilihat dari segi produktivitas, kualitas, efisiensi, fleksibilitas dan kepuasan. Untuk tingkat kepuasan masyarakat bisa kita lihat dari hasil penilaian Indeks Kepuasan Masyarakat yang di dalamnya terdapat 14 unsur pelayanan yang merupakan faktor penting dalam menentukan tingkat kepuasan masyarakat. Unsur-unsur tersebut diatur dalam Kep MenPAN Nomor 25 Tahun 2004. Faktor yang memengaruhi tingkat kepuasan masyarakat antara lain, penilaian terhadap kinerja aparat di kecamatan, ketepatan waktu juga biaya dalam mendapatkan pelayanan, keadilan mendapatkan pelayanan, serta kenyamanan dan keamanan dalam mendapatkan pelayanan.

\section{SARAN}

1. Pihak Kecamatan Jatinangor diharapkan dapat lebih meningkatkan produktivitas dan kualitas pelayanan Pelayanan Publik kepada masyarakat khususnya mengenai sosialisasi Pelayanan Publik, prosedur, kenyamanan, peningkatan sarana dan prasarana, dan kecepatan pelayanan Pelayanan Publik di Kantor Kecamatan Jatinangor. Untuk itu, dibutuhkan komitmen dari semua pihak, khususnya petugas yang terkait.

2. Perlu adanya Diklat minimal satu tahun sekali untuk aparat kecamatan dan menambah pegawai dengan cara mengusulkan penambahan tenaga honorer kepada pemerintah Kabupaten Sumedang sebagai tambahan operator 
bagi pelaksanaan Pelayanan Publik di Kecamatan Jatinangor.

3. Perlu dilakukan penilaian secara berkala mengenai Indeks Kepuasan Masyarakat sebagai acuan untuk mengevaluasi kekurangan-kekurangan pada setiap masing-masing unsur agar dapat meningkatkan terus mutu pelayanan khususnya Pelayanan Publik di Kantor Kecamatan Jatinangor.

\section{DAFTAR PUSTAKA}

Dwiyanto, Agus. 2011. Manajemen Pelayanan Publik. Yogyakarta: Gadjah Mada University Press

Hardiayansyah. 2011. Kualitas Pelayanan Publik: Konsep, Dimensi, Indikator dan Implementasinya. Yogyakarta: Gava Media

Lukman, Sampara. 2000. Manajemen Kualitas Pelayanan. Bandung: STIA LAN PRESS

Moenir, H.A.S. 2010. Manajemen Pelayanan Umum Di Indonesia. Jakarta: Bumi Aksara

Ratminto \& Atik Septi Winarsih. Manajemen Pelayanan. Yogyakarta: Pustaka Pelajar

Sedarmayanti. 2009. Reformasi Administrasi Publik, Reformasi Birokrasi, dan Kepemimpinan Masa Depan. Bandung: Refika Aditama
Siagian, P. Sondang. 2012. Manajemen Sumber Daya Manusia. Jakarta: Bumi Aksara.

Steers, Richard, M. 1985. Efektivitas Organisasi (Terjemahan Maghdalena Djamin). Jakarta: Erlangga

Sugiyono. 2013. Metode Penelitian Kombinasi (Mixed Methods). Bandung: Alfabeta

Sumaryadi, I Nyoman. 2005. Efektivitas Implementasi Kebijakan. Jakarta: Citra Utama

Wasistiono, Sadu. 2003. Manajemen Pemerintah Daerah. Bandung: Fokus Media

\section{Peraturan Perundang-Undangan}

Undang-Undang Nomor 25 Tahun 2009 tentang Pelayanan Publik

Keputusan Menteri Pendayagunaan Aparatur Negara Nomor 63 Tahun 2003 tentang Pedoman Penyelenggaraan Pelayanan.

Keputusan Menteri Pendayagunaan Aparatur Negara Nomor 25 Tahun 2004 tentang Pedoman Penyusunan Indeks Kepuasan Masyarakat Unit Pelayanan Instansi Pemerintah.

Peraturan Bupati Sumedang Nomor 46 Tahun 2004 tentang Pedoman Peningkatan Pelayanan Publik di Lingkungan Kabupaten Sumedang. 